\title{
Current Teaching Methods Used for English Language Teaching in Upper Elementary School and the Preferred Ones for the Lower Grades
}

\author{
Shereen Alhindi \\ Dept. of English Language Institute, King Abdulaziz University \\ King Abdulaziz University, P.O. Box 42801, Jeddah 21551, Saudi Arabia \\ E-mail: salimohammadalhindi@stu.kau.edu.sa \\ Maha Halabi (Corresponding author) \\ Dept. of English Language Institute, King Abdulaziz University \\ King Abdulaziz University, P.O. Box 42801, Jeddah 21551, Saudi Arabia \\ E-mail: mshalabi@kau.edu.sa
}

Received: February 13, 2021 Accepted: March 29, 2021 Published: April 2, 2021

doi:10.5296/elr.v7i1.18489

URL: https://doi.org/10.5296/elr.v7i1.18489

\begin{abstract}
There is no doubt that the teaching method has a significant effect on the student's outcome and the responsibility for choosing the right method falls on the teacher. With experience, the teacher will be able to decide which method will fit the student's needs. This research examines the most popular teaching methods and materials for teaching the English language in Saudi public schools, particularly in the upper elementary grades. It also aims to explore the perceptions of English language teachers of the methods and materials they consider to be the most effective in the teaching of lower elementary grades in Saudi public schools, who will be exposed to the English language for the first time. The sample of the study comprised 44 English teachers in Saudi public schools. The findings show that the majority of the English language teachers use Communicative Language Teaching (CLT) either alone or with other teaching methods. Moreover, most of them are willing to use it with the low grades of elementary. The findings also show that the most used materials in the classroom are videos, pictures, audiovisuals and the least used are written texts. These were the same materials that the teachers would like to use (with the same order of preference) for teaching the lower
\end{abstract}


elementary grades. The findings have implications for current English language teachers who are willing to change their way of teaching and future teachers who would benefit from being aware of the effective methods of teaching the elementary grades in particular.

Keywords: English language teaching methods, Teacher`s perceptions, Upper elementary grades, Lower elementary grades

\section{Introduction}

It is well known that the teacher's role is significant in students learning progress. One of the important decisions that this role demands is choosing the right teaching method to achieve the lesson objectives. In the English language classroom, the accomplishment of this goal will ensure the success of the educational process and enhance student's language competence. Teachers often change their teaching methods to fit their students' needs, cope with the changing classroom situation, or to suit the new educational decisions from higher authorities. Saudi Arabia is an example where introducing the English Language to Public schools went through different stages. Alshahrani (2016) assumed that the English language was introduced in secondary schools in Saudi Arabia in the late 1920s without a specific syllabus. Then in the $1950 \mathrm{~s}$, it was introduced with a syllabus in the intermediate and secondary schools. Finally, in 2012 it was introduced to the upper grades of elementary schools starting from Grade 4. Recently, a new decision has been issued by the Ministry of Education in Saudi Arabia to introduce the English language in the lower elementary grades in public schools starting from 2021.

\subsection{Statement of the Problem}

The new decision issued by the Ministry of Education in Saudi Arabia to introduce the English language for the lower grades of the elementary public schools starting from 2021 is expected to bring some challenges. English teachers who teach the upper elementary grades in public schools are likely the ones who will teach the lower grades. Therefore, those teachers teaching methods and materials should be explored to find out their effectiveness along with their perceptions related to the methods and materials they will use if they teach the lower grades of elementary school.

\subsection{The Aim of the Study}

- Explore the conventional methods and materials for teaching the English language to students of upper elementary grades in Saudi public schools.

- Explorer English teachers' perceptions of the effective methods and materials that should be used for the students of lower elementary grades in Saudi public schools.

\subsection{Research Questions}

1. What are the conventional methods for teaching upper grades of elementary students in Saudi public schools?

2. What are the English teachers' perceptions of the effective methods that should be used to teach the lower elementary in Saudi public schools? 


\subsection{The Importance of the Study}

The study aims to encourage English teachers who are using traditional methods and materials, to adopt alternative and effective teaching methods that would enable their students to achieve the required learning outcomes of their English language course. The study also aims to help English teachers to decide which teaching method should be used to teach the lower elementary grades by providing other's opinions and perceptions.

\section{Literature Review}

\subsection{The Positive Outcome of Studying a Second Language Early}

Some studies show the existence of successful cases of L2 acquisition in late learners like in Julie and Laura cases (Ioup, 1995). Other research on late learners showed that some of them scored within the native speakers range as seen in a study by Birdsong and Molis (2001) and Johnson and Newport (1989). However, according to Ortega (2014), the majority of evidence indicates the lower levels of ultimate attainment and more individual variability in late and adult L2 compared to the developmental levels of morphosyntactic and phonological competence that are very close to native-like in the early learner who begins to acquire the L2 before puberty. One of the research that corresponds with this finding is that of Abrahamsson and Hyltenstam (2009) who conducted a large-scale study on 195 Spanish/Swedish bilinguals of different ages. The participants identify themselves as native-like in their L2. On close examination, a small number of them who started their L2 acquisition after the age of 12 was considered as native-like in the L2, but the majority of the participants who had acquired the L2 before the age12 were perceived as native speakers of the L2.

A suggestion to introduce English during the first grade was made by Al-Tamimi (2019). Based on his findings, the English language should be introduced early in Saudi schools and not in the fourth grade because childhood is the ideal time for learning a language. Since age is an irreversible factor, it makes sense to introduce second language learning at an early age.

\subsection{Factors Affecting Student's Achievement Level in learning the English Language}

Alrabai (2016) mentions the problem of the low achievement level in learners that can be linked to internal factors including those related to the student self like motivation, and anxiety or external factors such as sociocultural, problems with the educational system, and EFL instruction like the curriculum, and the teaching method. Since the current study is related to the teaching methods and materials, this will be elaborated on in the literature review.

\subsection{The Teaching Method in Saudi Public Schools}

Different methods were invented in the quest for better students' learning outcomes. Ahmad (2014) states that English language learners have limited knowledge about the proper linguistic use in Saudi Arabia due to their teacher's use of traditional teaching methodologies and the prohibition of the use of the first language in classrooms. Alqahtani (2018, pp. 125-128) has classified the historical development of language teaching in Saudi contexts to three approaches: 
A. The Grammar Translation Method (GTM) was popular in Saudi Arabia from the $19^{\text {th }}$ century onwards. This method depends on using the L1 commonly for interaction with little attention to the target language (Richards \& Rodgers, 2014). The method has been criticized for its emphasis on writing instead of speaking and its weak outcomes in the learner's ability to communicate using the target language (Al-Seghayer, 2011). Therefore in the early 1950s, the teaching and learning of the English language shifted to the improvement of a student's oral skills.

B. After GTM, the Audio Lingual Method (ALM) was used, which is based on structural Linguistics, behavioral psychology, a focus on the language's oral/aural structure and on the teaching of the four language skills (listening and speaking before reading and writing) using drills and pattern practice (Richards \& Rodgers, 2014). After more than 20 years of using these approaches, the inability of learners to use English in real-life communication has been noticed. This resulted in a move towards improving learners' communication skills in the target language (Alqahtani, 2018).

C. Communicative Language Teaching (CLT) was agreed on to improve the learners' communication skills. Richards $(2005$, p. 2) considers CLT as an approach and defines it as "a set of principles about the goals of language teaching, how learners learn a language, the kinds of classroom activities that best facilitate learning, and the roles of teachers and learners in the classroom". The teachers' rejection of CLT and returning to traditional methods including GTM and ALM was noted. They cited the obstacles in implementing CLT in the classroom, such as lack of training, lack of resources, the absence of assessing instruments, student's low proficiency level, and others (Al Asmari, 2015).

Due to the previous obstacles mentioned by Al Asmari (2015), that forced English teachers to return to the old traditional teaching methods, it was necessary to do new research to explore if the situation had changed or was still the same. The research was also necessary to indicate which teaching method was expected to be implemented for teaching the new curriculum in the lower elementary grades in Saudi public schools.

The author of this study claims that most of the obstacles that English teachers in Saudi Arabia had faced earlier and forced them to use the old traditional teaching method have disappeared. And now, most of them are using teaching methods that focus on improving learners' communication skills especially CLT. Also, this study posits that English teachers are planning to use CLT to teach the new beginner students of the lower elementary grades in Saudi public schools.

\section{Research Methodology}

\subsection{Participants}

The participants were 44 Saudi English teachers (36 female and 8 male) who teach in Saudi public schools. All of them had at least one year of teaching experience. The responses were gathered using opportunity sampling, where members of the target population are selected for the purpose of the study if they meet certain practical criteria (Dörnyei, 2007). 


\section{Macrothink \\ Education and Linguistics Research \\ ISSN 2377-1356 2021, Vol. 7, No. 1}

\subsection{Instrument}

The data was collected via a questionnaire. The questionnaire consisted of closed-ended questions and few open-ended ones. The researcher formulated the questionnaire based on that of Fahd Al Malihi (2015) and Khalil and Kholofelo Semono-Eke (2020). The 16 questions (Appendix A) contain demographic, background, and others that reveal the English teacher's teaching methods, materials, and opinions.

\subsection{Procedure}

Google Forms were used to design the questionnaire which was distributed electronically through WhatsApp and Telegram in groups for the English teachers of the elementary grades. The participants were anonymized to adhere to the research ethics and they had the choice to quit participating in the study. It took 3 weeks to gather the responses which were used for research purposes only.

\subsection{Data Analysis}

The closed-ended questions data were analyzed using the calculation and percentage mode and illustrated graphically in charts and bar graphs. The data for the open-ended questions were organized using Microsoft Excel and, analyzed by the researcher before being presented in the charts and bar graphs.

\subsection{Questionnaire Validity}

In order to test the questionnaire's validity, it was passed by the supervisor of the study and two English teachers who made suggestions and minor modifications to the questions in terms of rephrasing, arrangement, clarity, and comprehensibility.

\section{Results and Discussion}

\subsection{Gender}

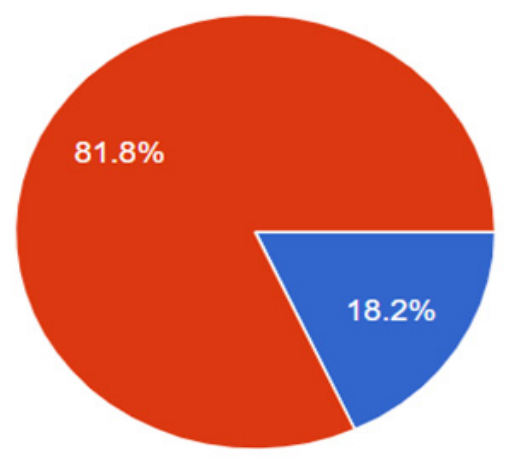

Figure 1. The participant's gender 


\section{Macrothink

The participants were asked to identify their gender first. This was to make sure that the questionnaire got both male and female responses. ( 8 male, 36 female).

\subsection{Qualification}

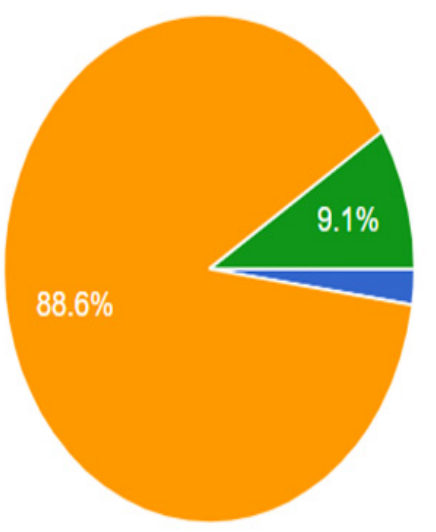

Diploma

Educational faculty

Bachelor degree

Master degree

$\mathrm{PhD}$

Figure 2. Qualification of the respondents

The chart illustrates that $88.6 \%(n=39)$ of the participant have a bachelor degree, $9.1 \%(n=4)$ respondents have a master's degree, and only $2.3 \%(n=1)$ have a diploma.

\subsection{Experience in Teaching English to Elementary Grades}

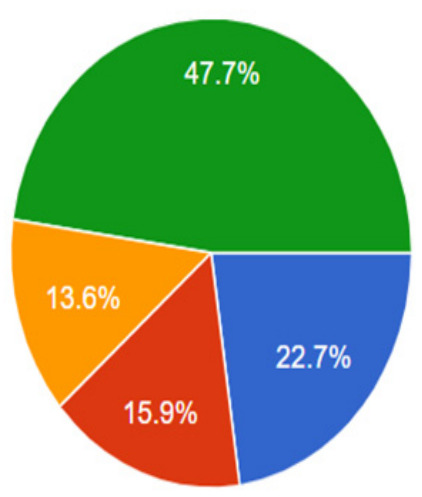

$$
\begin{aligned}
& 1-2 \text { years } \\
& 3-4 \text { years } \\
& 5-6 \text { years } \\
& 7-8 \text { years }
\end{aligned}
$$

Figure 3. Teaching experience for elementary grades

The chart above shows that $47.7 \%(n=21)$ of the participants have 7-8 years of experience in teaching the English language, $22.7 \%(n=10)$ have $1-2$ years of experience, $15.9 \%(n=7)$ have 3-4 years of experience while $13.6 \%(n=6)$ have $5-6$ years of experience. 
4.4 Which Stage of Elementary Did/Are You Teach/Teaching?

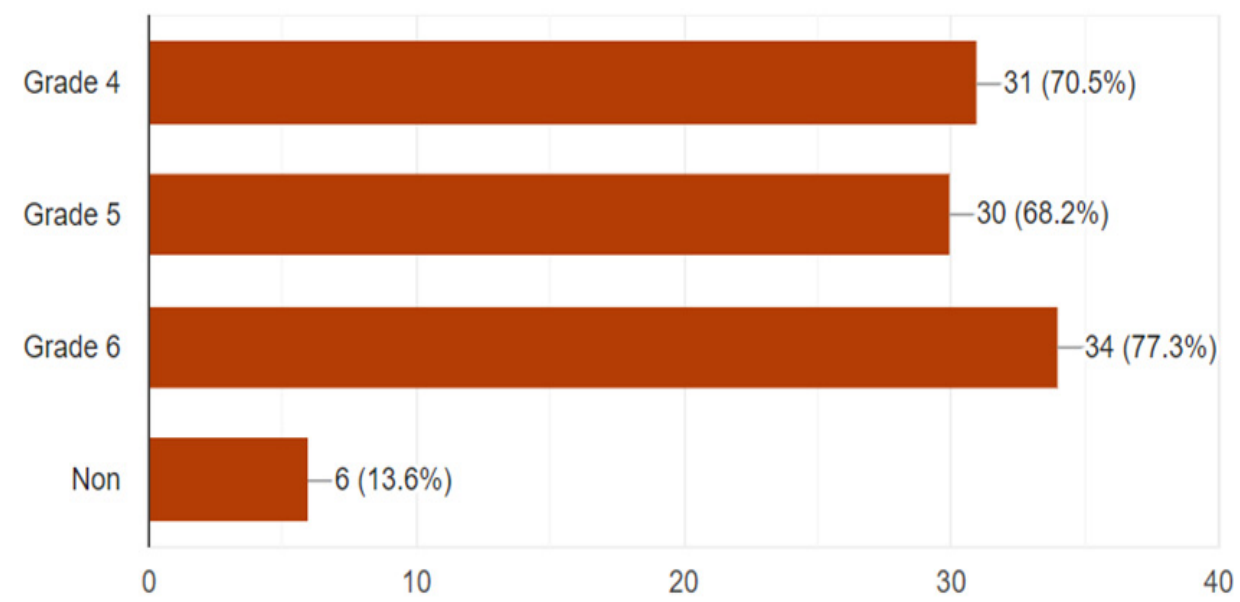

Figure 4. Experience in teaching upper elementary grades

The bar graph above shows that most of the respondents teach or have taught the English language to upper elementary grades. This question`s purpose was to make sure that most participants had experience in teaching those grades.

4.5 Which Other Levels Have You Had Previous Experience in Teaching?

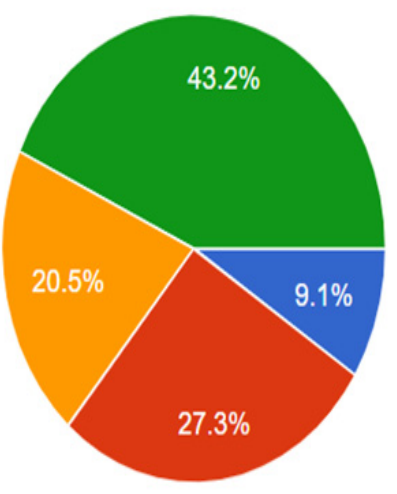

None

Secondary

Intermediate

Both

Figure 5. Experience in teaching the English language to other grades than elementary

This chart shows that $90.9 \%(n=40)$ of the respondents have experience in teaching other grades and only $9.1 \%(n=4)$ have experience in teaching Elementary only. 
4.6 Which Methods of Teaching Elementary Grades Did/Do You Use?

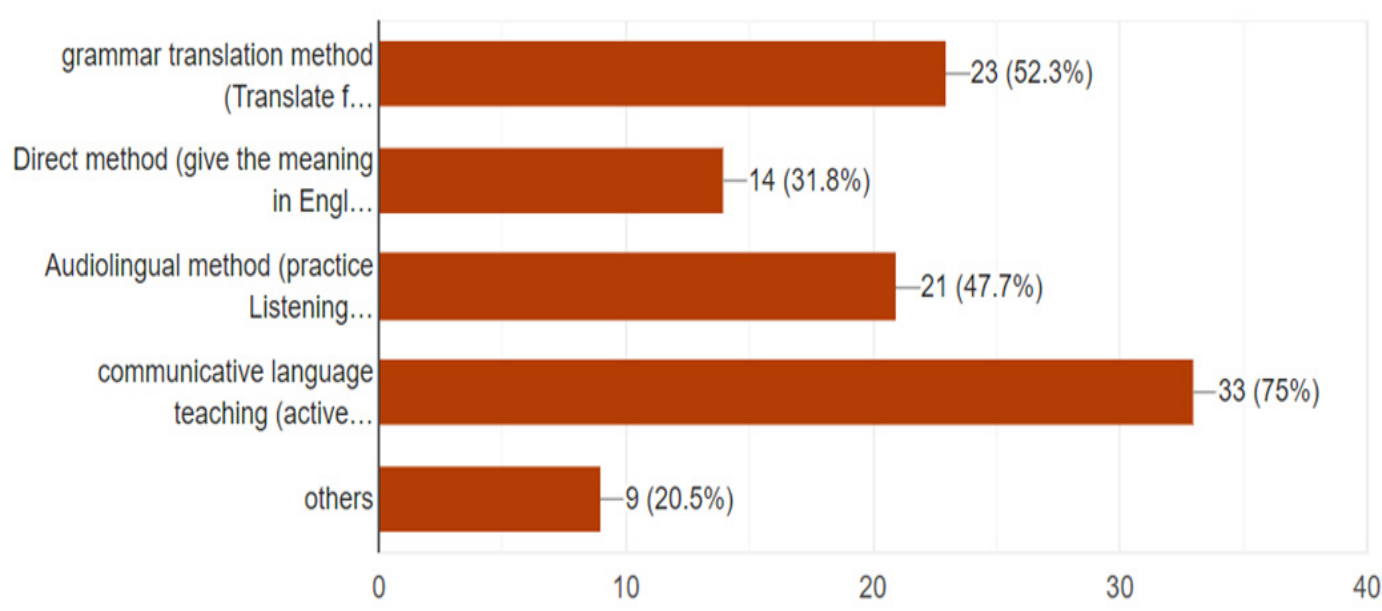

Figure 6. Methods that are mostly used in teaching elementary grades

The bar graph shows that the most common teaching method that teachers use in their class was CLT with a percentage of $75 \%(\mathrm{n}=33)$. Analyzing this percentage in detail leads to the conclusion that $54.55 \%(n=24)$ teachers use it along with other methods and $20.45 \%(n=9)$ teachers use it as their only method. The second most used method was the Grammar Translation method with a percentage of $52.3 \%(n=23)$. After detailing this percentage it was found that $45.48 \%(n=20)$ of the teachers use it with other methods and $6.82 \%(n=3)$ of the teachers use it as their only method. The third most used method was the Audiolingual method with a percentage of $47.7 \%(n=21)$. All these teachers used it with other methods but never alone. The fourth most used method was the Direct method with a percentage of $31.8 \%$ $(n=14)$. Detailing this percentage shows that $24.99 \%(n=11)$ of the teachers use it with other methods and only $6.8 \%(\mathrm{n}=3)$ of them use it as their only method. $20.5 \%(\mathrm{n}=9)$ of the teachers illustrate that they use other methods in addition to the ones mentioned in this question.

The result of this questionnaire clearly shows that CLT is becoming the most used teaching method in Saudi Arabian public schools for teaching the English language and the situation that forced English teachers to return to the old traditional teaching methods has changed since Al Asmari (2015). The current study's first claim, which was the disappearance of most obstacles that English teachers in Saudi Arabia faced earlier and which had forced them to use the old traditional teaching method, was proved by this study. It is now evident that most of them are using teaching methods that focus on improving learners' communication skills which is mainly the CLT approach. 


\section{Macrothink}

4.7 From Your Experience Which Method Was the Best for Teaching Upper Elementary Students?

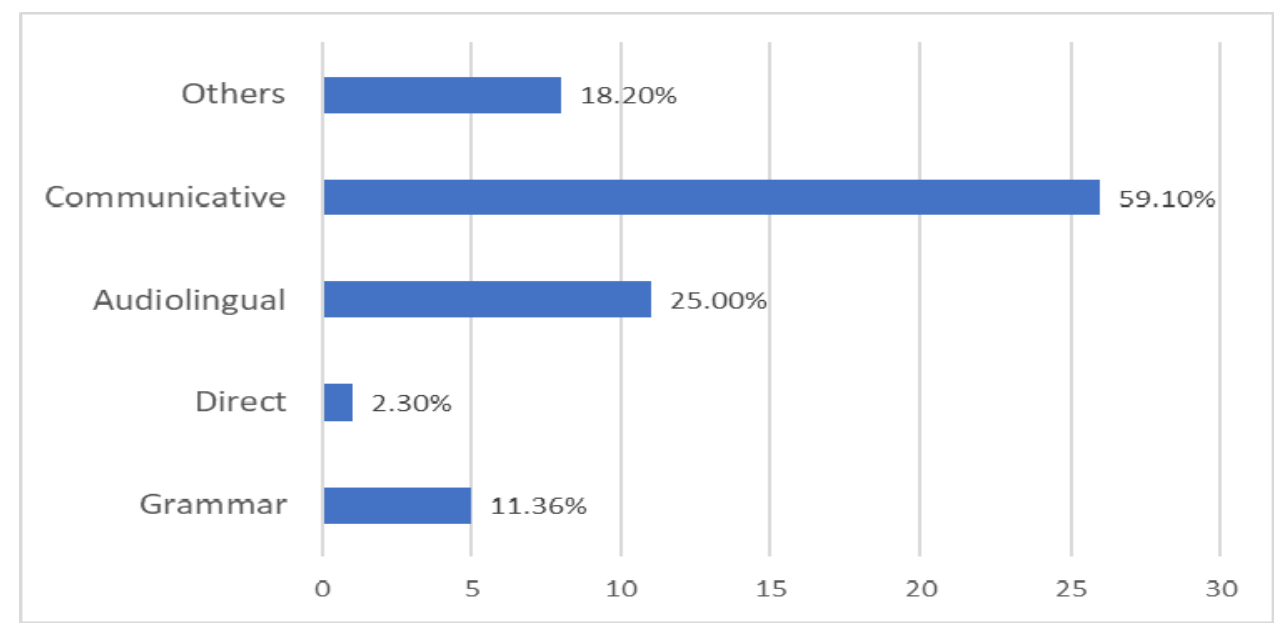

Figure 7. The best method to use in teaching upper elementary students

This question was open-ended and its purpose was to clarify the most favored method of teaching upper elementary students which might not be fully answered in the closed-ended questions. The bar graph clearly shows that CLT is the best approach with a percentage of $59.1 \%(n=26)$ followed by the Audiolingual method with a percentage of $25 \%(n=11)$. A percentage of $18.2 \%(n=8)$ of the teachers mentioned other methods especially the cooperative method $(n=2)$, but the rest of the answers in this category were either left empty by the participants or with no actual value. The Grammar translation method was chosen by $11.36 \%(n=5)$ and the Direct method was chosen by $2.3 \%(n=1)$.

4.8 What Are Your Reasons for Choosing This Method to be the Best in teaching Upper Elementary Students?

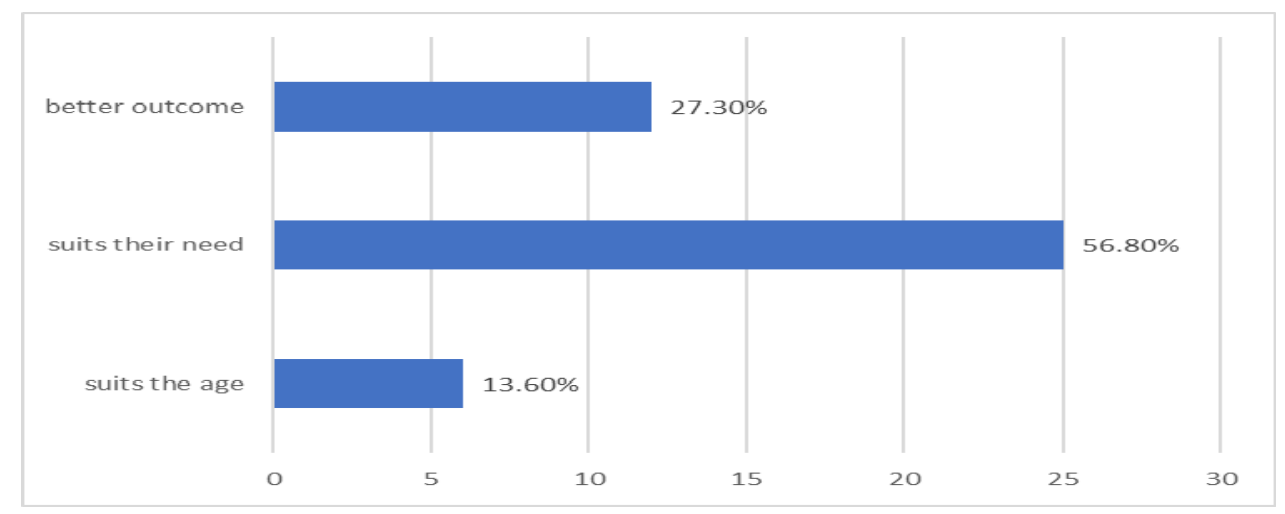

Figure 8. Reasons for choosing these methods to teach upper elementary students

This question was an open-ended one to collect as much information as possible for the 


\section{Macrothink}

Education and Linguistics Research

ISSN 2377-1356

2021, Vol. 7, No. 1

teachers' preference for the teaching methods they use. After analyzing the reasons it was found that they fall into three categories as shown in the bar graph above. The first reason was that the method suited the students' needs with a percentage of $56.8 \%(n=25)$. The second reason was better student learning outcomes with a percentage of $27.3 \%(n=12)$. The third reason was the method suited the student's age with a percentage of $13.6 \%(n=6)$. None of the answers show any obstacle that forces the teachers to choose the method.

\subsection{What Teaching Materials do You Use in Elementary Class?}

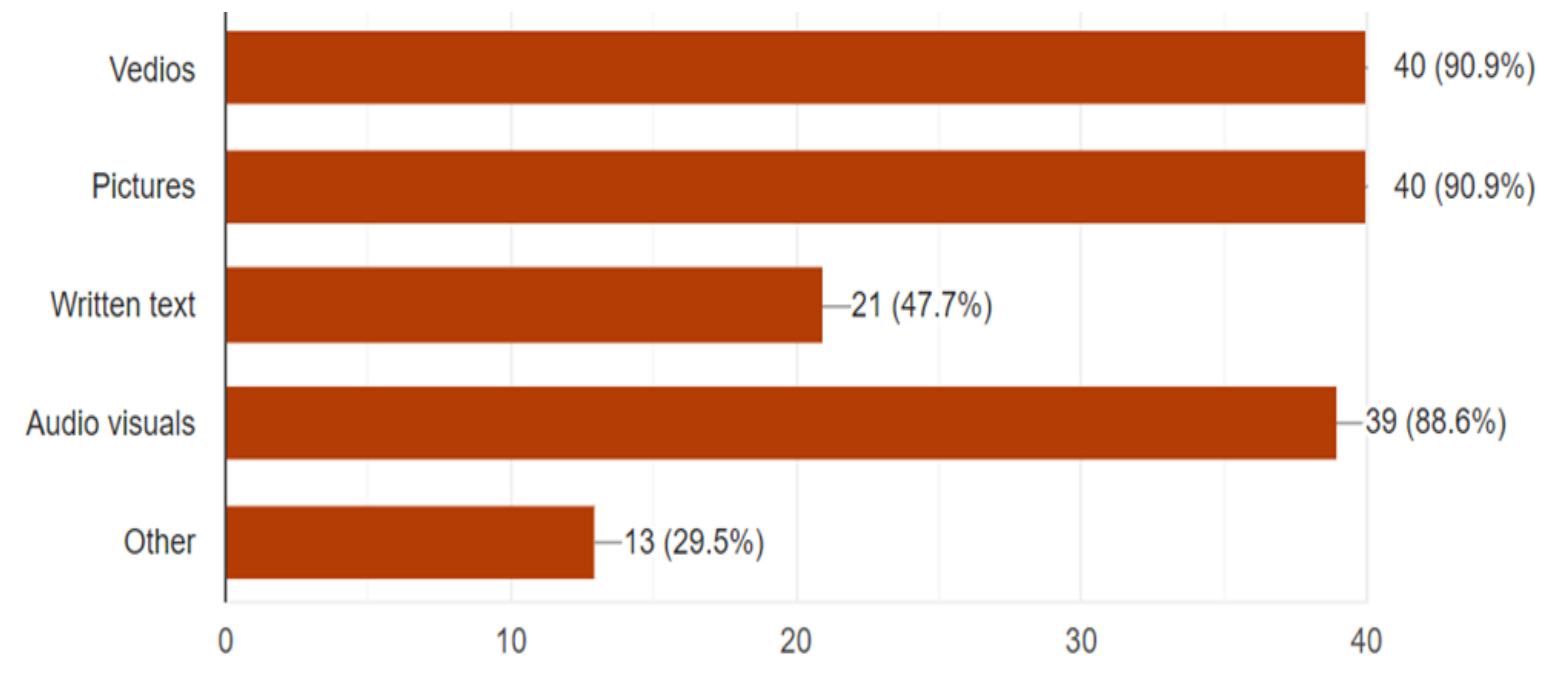

Figure 9. Teaching materials used in the classroom

This bar graph shows the materials that are used in the classroom such as videos, pictures, and audiovisuals with a percentage of $90.9 \%(n=40)$ for nearly all of them. Written text materials were used by $47.7 \%(n=21)$ of the teachers while $29.5 \%(n=13)$ of teachers used other materials than the ones mentioned in the question.

4.10 Do You Agree With Introducing the English Language for the Lower Elementary Grades in Public Schools?
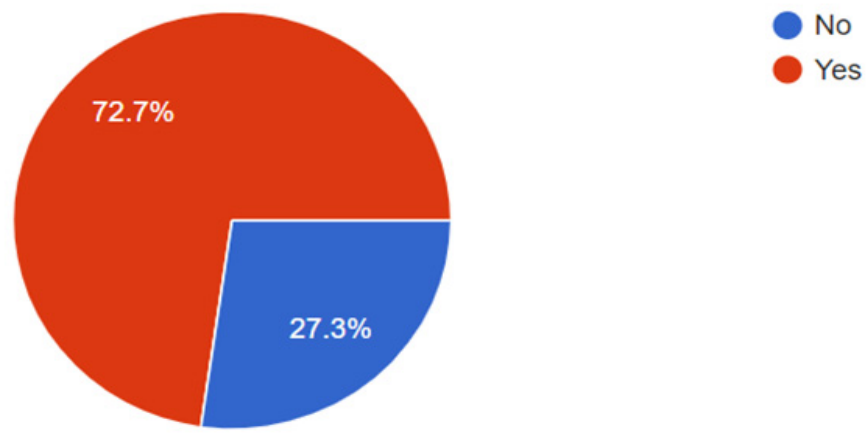

Figure 10. Approval for introducing the English language for the low elementary grades 


\section{Macrothink}

Education and Linguistics Research

ISSN 2377-1356 2021, Vol. 7, No. 1

The chart reveals that $72.7 \%(n=32)$ of the respondents approve the decision of introducing the English language for the lower elementary grades while $27.3 \%(n=12)$ disagree with the decision. This percentage of teachers is considered to be rather high, and it must be taken into account and the reasons for its rejection must be explored.

\subsection{Do You Agree to Teach the Lower Grades in Elementary School?}

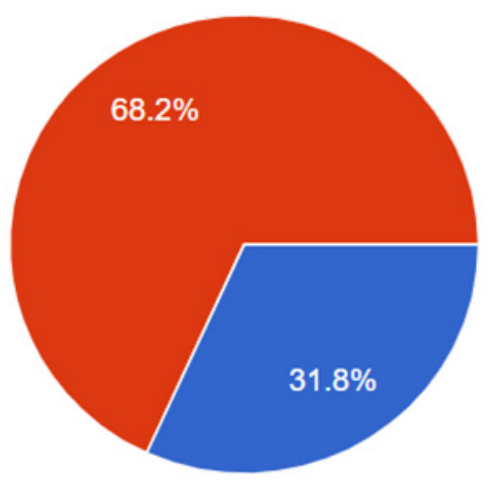

Figure 11. Approval to teach the lower grades of elementary

This chart illustrates that $68.2 \%(n=30)$ of the respondent teachers agree to teach the lower grades while $31.8 \%(n=14)$ do not.

4.12 Have You Had Any Training Program to Teach Young Learners?

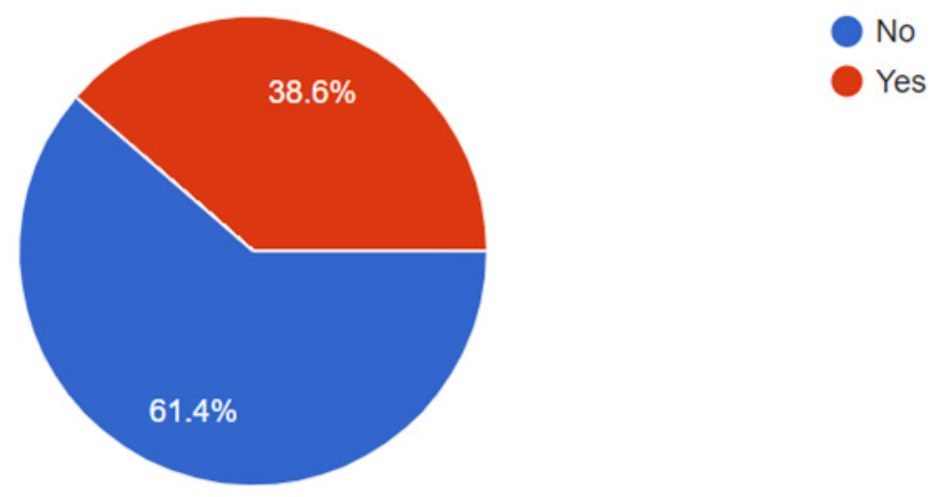

Figure 12. Teachers who had been trained to teach young learners

In this chart, $38.6 \%(\mathrm{n}=17)$ of the teachers reveal that they were previously involved in a training program related to teaching theory and pedagogy for young learners while $61.4 \%$ $(n=27)$ did not. It was found that most of the teachers who were not trained to teach young learners disagreed with introducing the English language to the lower elementary grades. 


\section{Macrothink}

Education and Linguistics Research

ISSN 2377-1356 2021, Vol. 7, No. 1

4.13 Are You Fully Aware of the EFL Young Learners Teaching Policy in Saudi Arabia?

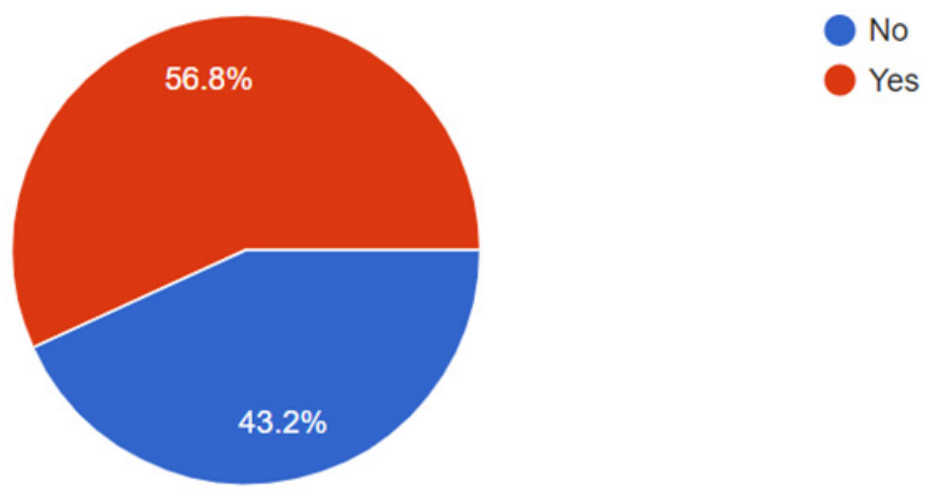

Figure 13. Awareness of the EFL young learners teaching policy in Saudi Arabia

This chart illustrates that $56.8 \%(n=25)$ of the respondent teachers are fully aware of the EFL young learners' teaching policy in Saudi Arabia while 43.2\% $(\mathrm{n}=19)$ are not.

4.14 If You Teach Lower Grade Elementary Students What Teaching Method do You Think Would Suit Them the Most?

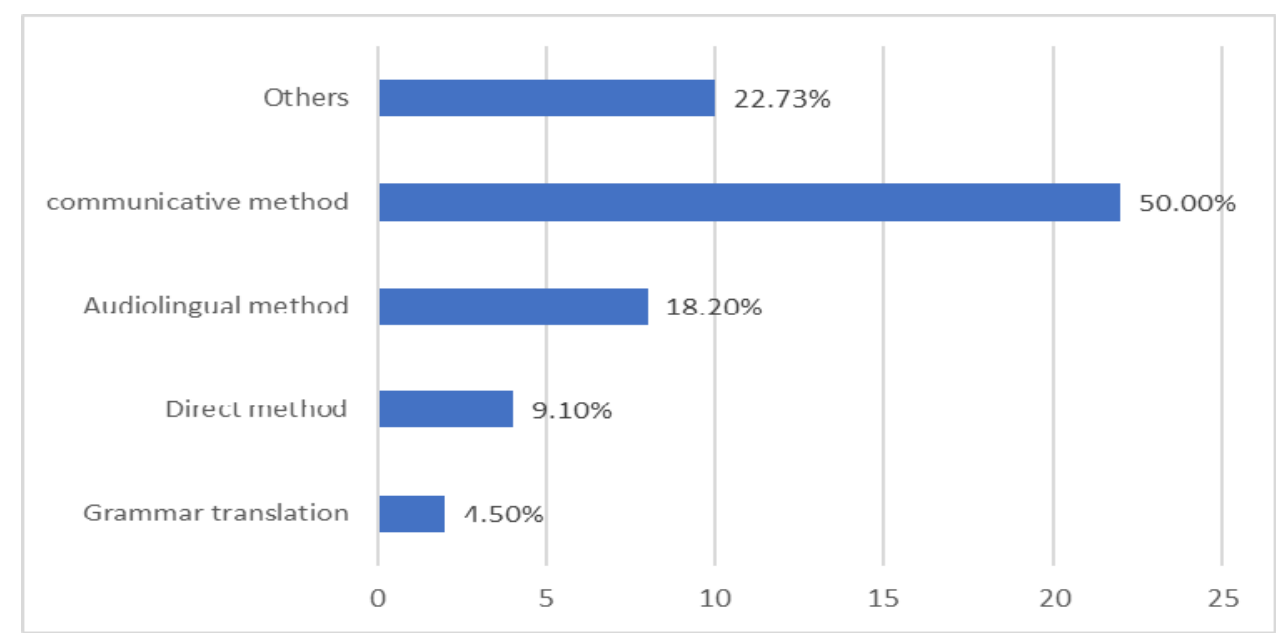

Figure 14. The preferred teaching method by the teachers to use in teaching lower grade of elementary

This question was open-ended and its purpose was to clarify the most preferred method to teach the lower elementary grades. The bar graph clearly shows that CLT is the most preferred method with a percentage of $50 \%(\mathrm{n}=22)$ followed by the Audiolingual method with a percentage of $18.2 \%(n=8)$. A percentage of $22.73 \%(n=10)$ of the teachers mentioned other methods especially the Cooperative method $(n=2)$, but the rest of the answers that fill in this category were left empty by the participants or with no actual value. The Grammar 


\section{Macrothink}

Education and Linguistics Research

ISSN 2377-1356 2021, Vol. 7, No. 1

translation method was chosen by $4.5 \%(\mathrm{n}=2)$ and the Direct method was chosen by $9.1 \%$ $(\mathrm{n}=4)$.

The results clearly show that English teachers are planning to use CLT to teach the new beginner students of the lower grades of elementary school and therefore is in agreement with the second claim of this study.

\subsection{What Are Your Reasons for Choosing This Teaching Method to Lower Grade Elementary} Students?

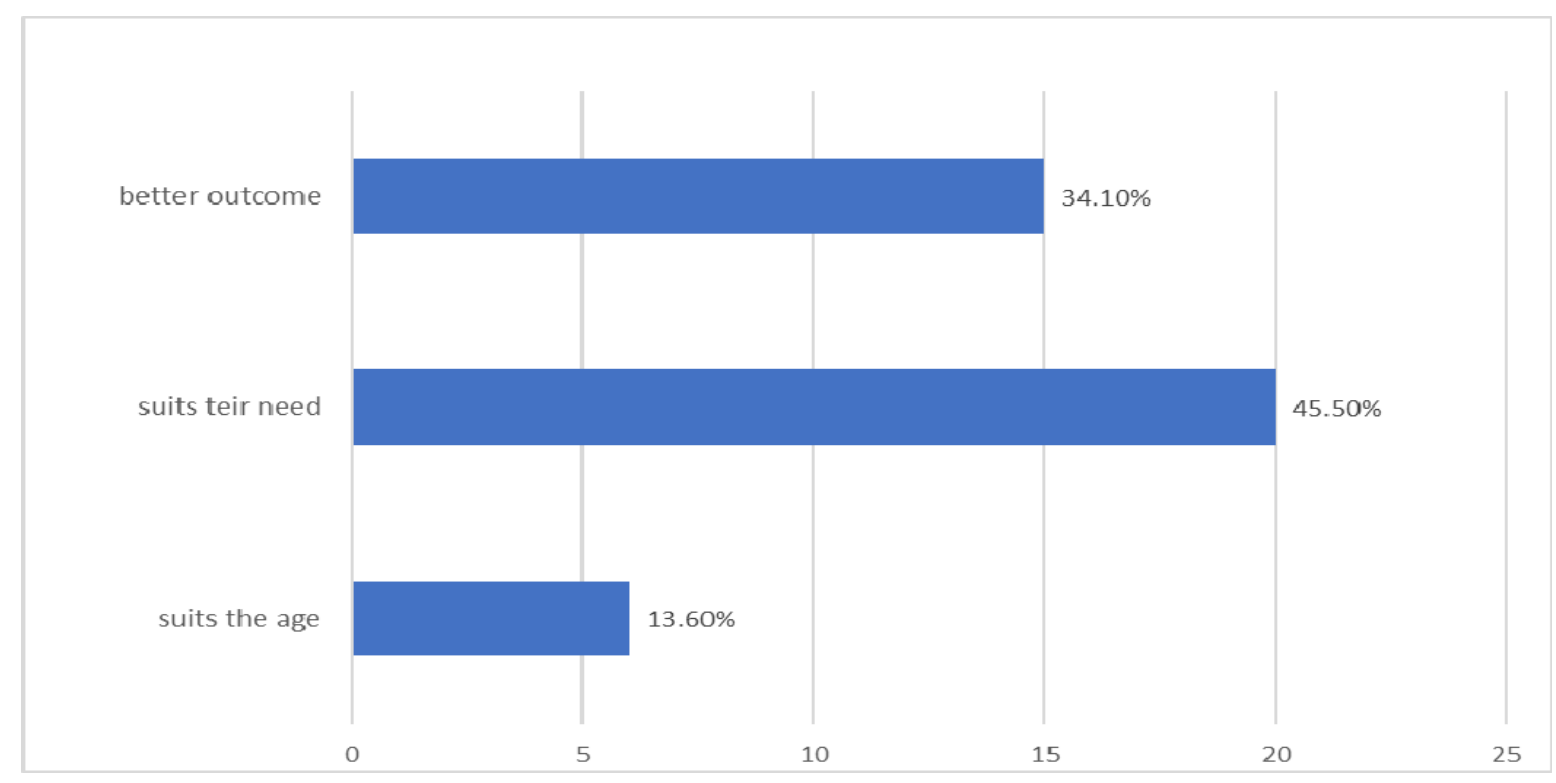

Figure 15. Reasons for choosing these methods to teach lower elementary students

This question was an open-ended one to collect as many reasons as possible to determine the ideal teaching method for future lower elementary grade students. After analyzing the reasons it was found that they fall into three categories as shown in the bar graph above. The first reason was the method suited the student's needs with a percentage of $45.5 \%(n=20)$. The second reason was better student learning outcomes with a percentage of $34.1 \%(n=15)$. The third reason was the method suited the student's age with a percentage of $13.6 \%(n=6)$.

4.16 What Teaching Materials Will You Use? 


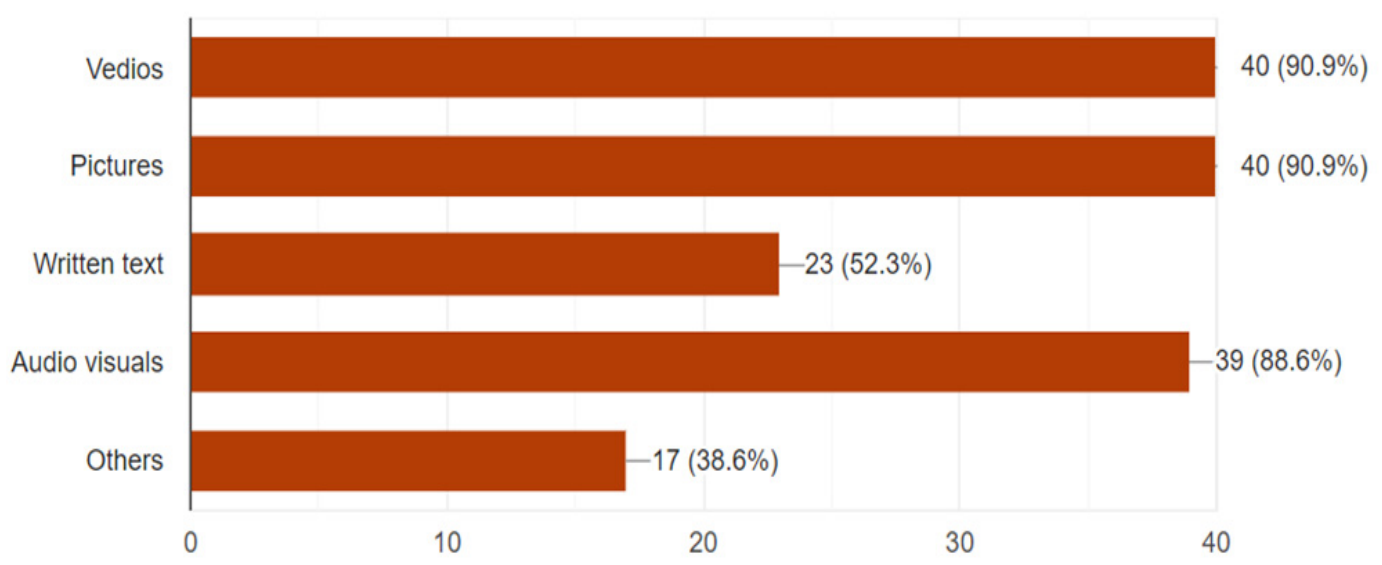

Figure 16. Teaching materials that teachers are willing to use to teach lower elementary grades

This bar graph shows that the materials which the teachers are planning to use are videos, pictures, and Audiovisuals with a percentage of $90.9 \%(\mathrm{n}=40)$ for nearly all of them. Written text materials were chosen by $52.3 \%(n=23)$ of the teachers while $38.6 \%(n=17)$ of the teachers chose other materials than the ones mentioned in the question.

\section{Conclusion}

This study has two aims. First, it explores the conventional methods and materials for teaching the English language to students of upper elementary grades in Saudi public Saudi schools. Second, it explores English teachers' perceptions of the effective methods and materials to teach the students of the upper elementary grades in Saudi public schools. The results of the study suggest that CLT is the preferred teaching method currently used to teach the upper elementary grades but mostly used with other methods according to the student's needs. Also, it was found that CLT is the preferred method to use in the future to teach the lower grades. The result shows that the materials used in the classroom in order from the highest percentage to the least are videos, pictures, audiovisuals, and written texts. These were the same materials with the same percentage that teachers prefer to use in the future for teaching the lower elementary grades.

The findings of the study are useful for teachers who are questioning their teaching method and who are trying to decide whether to choose CLT as their main teaching method and blend other methods to fit their students' needs.

\section{References}

Abrahamsson, N., \& Hyltenstam, K. (2009). Age of onset and nativelikeness in a second language: Listener perception versus linguistic scrutiny. Language learning, 59(2), 249-306. https://doi.org/10.1111/j.1467-9922.2009.00507.x

Ahmad, A. M. (2014). Kumaravadivelu's Framework as a Basis for Improving English 
Language Teaching in Saudi Arabia: Opportunities and Challenges. English language teaching, 7(4), 96-110. https://doi.org/10.5539/elt.v7n4p96

Al-Seghayer, K. (2011). English teaching in Saudi Arabia: Status, issues, and challenges: Hala.

Al-Tamimi, R. (2019). Policies and Issues in Teaching English to Arab EFL Learners: A Saudi Arabian Perspective. Arab World English Journal, 10(2), 68-76. https://doi.org/10.24093/awej/vol10no2.6

Al Asmari, A. A. (2015). Communicative language teaching in EFL university context: Challenges for teachers. Journal of Language Teaching and Research, 6(5), 976-984. https://doi.org/10.17507/j1tr.0605.09

Alqahtani, S. M. A. (2018). Teaching English in Saudi Arabia. In English as a Foreign Language in Saudi Arabia (pp. 120-137): Routledge. https://doi.org/10.4324/9781315 688466-6

Alrabai, F. (2016). Factors underlying low achievement of Saudi EFL learners. International Journal of English Linguistics, 6(3), 21-37. https://doi.org/10.5539/ijel.v6n3p21

Alshahrani, M. (2016). A brief historical perspective of English in Saudi Arabia. Journal of Literature, Languages and Linguistics, 26, 43-47.

Birdsong, D., \& Molis, M. (2001). On the evidence for maturational constraints in second-language acquisition. Journal of Memory and language, 44(2), 235-249. https://doi.org/10.1006/jmla.2000.2750

Dörnyei, Z. (2007). Research methods in applied linguistics: Quantitative, qualitative, and mixed methodologies: Oxford University Press Oxford.

Fahd Al Malihi, J. (2015). Saudi EFL Teachers' Readiness and Perceptions of Young Learners Teaching at Elementary Schools. English language teaching, 8(2), 86-100. https://doi.org/10.5539/elt.v8n2p86

Ioup, G. (1995). Evaluating the need for input enhancement in post-critical period language acquisition. The age factor in second language acquisition, 95-123.

Johnson, J. S., \& Newport, E. L. (1989). Critical period effects in second language learning: The influence of maturational state on the acquisition of English as a second language. Cognitive psychology, 21(1), 60-99. https://doi.org/10.1016/0010-0285(89)90003-0

Khalil, D., \& Kholofelo Semono-Eke, B. (2020). Appropriate Teaching Methods for General English and English for Specific Purposes from Teachers' Perspectives. Arab World English Journal (AWEJ) Volume, 11. https://doi.org/10.24093/awej/vol11no1.19

Ortega, L. (2014). Understanding second language acquisition: Routledge. https://doi.org/10.4324/9780203777282

Richards, J. C. (2005). Communicative language teaching today: SEAMEO Regional 
Language Centre Singapore.

Richards, J. C., \& Rodgers, T. S. (2014). Approaches and methods in language teaching: Cambridge university press.

\section{Appendix}

\section{Appendix A}

The methods of public school teachers in teaching English to the upper elementary grades and their perception of the appropriate method to use in teaching lower elementary grades

This questionnaire is directed to English language teachers or teachers with previous experience in teaching English to public elementary schools. The aim is to investigate the methods of teaching used to teach upper elementary grades and the preferred method to use in teaching the lower elementary grades in the future.

Thank you so much

Shereen Alhindi

1. Gender

- Male

- Female

2. Qualification

- Diploma

- Educational faculty

- Bachelor degree

- Master degree

- $\mathrm{PhD}$

3. Experience in teaching English to elementary grades

- 1-2 years

- 3-4 years

- 5-6 years

- 7-8 years 


\section{Macrothink

4. Which stage of elementary did/are you teach/teaching?

- Grade 4

- $\quad$ Grade 5

- Grade 6

- None

5. Which other levels have you had previous experience in teaching?

- Secondary

- Intermediate

- Both

- None

6. Which methods of teaching elementary grades did/do you use?

- Grammar translation method (translate from English to Arabic )

- Direct method (give the meaning in English )

- Audiolingual method hello (practice listening and speaking in English using drills and Patterns)

- Communicative language teaching (active student interaction, role play, games)

- Others

7. From your experience which method was the best for teaching upper elementary students?

8. What are your reasons for choosing this method as the best in teaching upper elementary students?

9. What teaching materials do you use in elementary class?

- Videos

- Pictures

- Written texts 


\section{Macrothink}

- Audiovisuals

- Others

10. Do you agree with introducing the English language for the lower elementary grades in public schools?

- No

- Yes

11. Do you agree to teach the lower grade in elementary school?

- $\quad$ No

- Yes

12. Have you had any training program to teach young learners?

- $\quad$ No

- Yes

13. Are you fully aware of the EFL young learners teaching policy in Saudi Arabia?

- $\quad$ No

- Yes

14. If you teach lower grade elementary students what teaching method do you think would suit them the most?

15. What are your reasons for choosing this teaching method to teach lower elementary grade students?

16. What teaching materials will you use?

- Videos

- Pictures

- Written texts

- Audiovisuals 


\section{Macrothink

- Others

\section{Copyright Disclaimer}

Copyright reserved by the author(s).

This article is an open-access article distributed under the terms and conditions of the Creative Commons Attribution license (http://creativecommons.org/licenses/by/4.0/). 